\section{Research Square}

Preprints are preliminary reports that have not undergone peer review.

They should not be considered conclusive, used to inform clinical practice, or referenced by the media as validated information.

\title{
Bacteriological and Physicochemical Assessment of Water Quality of the Public Swimming Pools in Klang Valley Malaysia
}

Muhammad Naim Rosli ( $\square$ zac.effon013@gmail.com )

Management \& Science University (MSU) https://orcid.org/0000-0002-0920-6641

Research Article

Keywords: Microbial Quality, Physicochemical Assessment, Safety, Swimming Pools, Bacteriological Quality

Posted Date: November 12th, 2020

DOI: https://doi.org/10.21203/rs.3.rs-106788/v1

License: (c) This work is licensed under a Creative Commons Attribution 4.0 International License. Read Full License 


\section{Abstract}

Background: Water is essential for life and it is used for various activities such as drinking, bathing, and recreational purposes and also one of the modes of the transmission of the disease.

Objective: The objective of this study to assess the present of bacteriological and the standard of physicochemical quality of swimming pools' water in Lembah Klang, Malaysia.

Methodology: Seven water sample collected from outdoor and indoor swimming pools (hotel, apartment and public swimming pool) in Lembah Klang, Malaysia. The water samples were collected in sterile bottles (30 ml). Physicochemical parameters were determined using water quality testing kit pH \& chlorine apparatuses. The water sample than had cultured and incubated. The presence of bacteria was counted by total bacterial count method.

Result: The ranges of mean values of the various chlorine level parameters of the selected water samples investigated for the apartment, hotel and municipal were, $0.56 \pm 1.01,0.77 \pm 0.95$ and $1.19 \pm 0.91$. All the physicochemical parameters except conductivity values were within the permissible limits of the World Health Organization (WHO) standards 2006 and American National Standard for Water Quality in Public Pools and Spas (ANSI/APSP) 2015. The mean standard plate count of water samples from the selected apartment, hotel, and municipal's swimming pools were, $28407.14 \pm 28469.05,8192.86 \pm 10556.36$ and $3257.14 \pm 6250.17$ which above the WHO Guideline limit, thus signifying contamination.

Conclusion: The study recommends improvement in personal hygiene of swimmers, adequate cleansing of the pools and enforcement of standards by the government.

\section{Introduction}

All the way through history from regeneration to regeneration, swimming has been popular in practically in the humanities and nations. As the sciences and technology evolved, thoughts about the risks of disease transmission associated with swimming in the pond, ocean or swimming pool, in recent history. Moreover, different public health scientists unthinkingly assumed that there could be a relation between the unit of fecal contamination as well as contamination from bathers and the risk of acquiring certain illnesses during swimming activities, this relation was not effectively demonstrated until the 1950s which research had done by Moore B in article name Sewage contamination of coastal bathing waters in England and Wales.

However, the Centers for Disease Control and Prevention (CDC) has recently reported that there have been numerous epidemics of disease as a result from using public swimming pools, precisely the existence of the Protozoan Cryptosporidium. This has been occurring because many public pools had not correctly cleaned (Brad Kelechava, et al., 2015) [1]. The endorsed to the pollution of the swimming pool in the study area by fecal substance and other firm waste materials. This benefaction has recognized as pretention for some public health risks to users, due to the contamination of swimming pool water. Bacterial contamination toward the swimming pool water can result in pathogenic bacteria, causing infections to swimmers. Nevertheless these contaminants can be obtainable into swimming pool water from swimmers, from the pool filters or occasionally from defects in pool engineering (George Osei-Adjei, et al., 2014).[2] Notwithstanding, recreational waters may contaminate by direct excretion by bathers (vomits, urine, etc.), transport on the body or growth within the filter bed (Hoseinzadeh E, et al., 2013) [3].

In many cases, waterborne infectious causing diarrhea and the most common bacteria with a total of three thousand cases reported every year in the United States alone (Yoder et al., 2012a, 2012b)[4,5]. According to the Malaysia Health Ministry, the prevalence in 2013 of waterborne, typhoid, cholera, hepatitis A and dysentery were $47.79,0.73,0.58,0.41$ and 0.28 per 100,000 of the population correspondingly reported in 2013 (Dr. Milton Lum, 2015) [21]. The Infections caused by swallowing the contaminated water by bacteria and fungi reported in most recent years, from swimmers (Brewster et al., 1994; Kiyohara et al., 2006) [6, 7]. The risk of infection and disease linked to the contaminated of the swimming pool water, consequently some due to the fecal related by the bather or contaminated source of water or may be due to the directly contaminated animals (birds, frogs or mouse) (WHO, 2006)[6,7]. In addition, fecal matter contributes to the water when a person has an accidental fecal release (diarrhea stool) or when individual fecal material on swimmers' bodies washed into the pool (CDC, 2001a)[10]. Conversely, some other causes are due to non-fecal human shedding such as vomiting, skin disease, mucus or saliva in the swimming pools give the potential to transmit the microorganisms (pathogens). Moreover, fungi and virus may also lead to skin infection which comes to the infected water. The main pathogens mostly bacteria can also be the shield from the user and transmitted I water (WHO, 2006; Kokebe Yedeme, et al., 2017) [8, 11].

\section{Methodology}

\subsection{Study design}


The study had conducted in Klang Valley, Malaysia between Junes until August 2016. The research is a cross-sectional study. This study does not have time dimension it depends on the differences existing on behalf of change the following intervention and the sample are select based on existing differences on behalf of random allocation. The cross-sectional design measure through alternatively a process of change.

\subsection{Study area}

The Study piloted in Klang Valley, Malaysia mostly the sample collected at the Apartments, hotels and public swimming pool around the Klang Valley area. Thus, Klang Valley is attractive and developing country and also the center of Malaysia. It the most popular area of leaving, tourism and underwritten through a faster development compared to other cities in Malaysia. The area of Klang Valley is $2900 \mathrm{KM}$ and located in the center of Selangor State, It located at the West Coast of Malaysia with a widespread range of flat land than the East Coast of Malaysia with a population of almost 7.53 million peoples in 2015 (Jabatan Perangkaan Malaysia, 2015)[12]. The temperatures remain constant. The maximums temperature is in between $320 \mathrm{C}$ and $33^{\circ} \mathrm{C}$ and not exceed more than $38.5^{\circ} \mathrm{C}$, while minimums temperature is in between $23.40 \mathrm{C}$ and $24.6^{\circ} \mathrm{C}$ and have never fallen below $14.4^{\circ} \mathrm{C}$. Klang Valley had received a minimum amount of 2,600 mm rain in a year and in June to July are relatively dry but mostly it will exceed 131 millimeters per month.

\subsection{Sample size calculation}

This samples size will determine the objective of the research which to determine the bacteriological count In of the Public Swimming Pools in Klang Valley, Malaysia. By using the Statistical Package for the Social Sciences (SPSS) version 24.0. This software calculates the sample size needed for the sample.

\subsection{Data analysis}

The research using a Pearson correlation coefficient test. The data collection will be systematically arranged, and the resulting data tabulated and entered using specific program used to develop the analysis which is using Statistical Package for the Social Sciences (SPSS) version 24.0 and Microsoft Excel 2010.

\subsection{Physicochemical analysis of the water samples}

Chlorine and $\mathrm{pH}$ determined by using the rainbow model 78 all in one test kit for the pool or spa. The temperature measured at the poolside by using a standard $100^{\circ} \mathrm{C}$ thermometer.

\subsection{Bacteriological analysis of the water samples}

Bacteriological indicators, plate count agar serial dilution method used to determent the amount of the bacteria and it was incubated at $37^{\circ} \mathrm{C}$ for 24 hours for all colony counting (WHO, 2006; APHA, 1998)[8,13] All microbial analysis was done by following strict aseptic techniques of microbiology procedures. All the data collected and analyze by using SPSS and Microsoft Excel 2010. To fine the mean and stander deviation of the bacteria.

\section{Results And Analysis}

\subsection{Prevalence of chlorine level and bacteriological status}

The study in chlorine level in apartment shown that there are about $85 \%$ water sample in apartment, low in chlorine level and $15 \%$ water sample in apartment, high chlorine level. The standard plate count was $100 \%$ contaminated for the apartment. For hotel, the chlorine level is much similar to the apartment, there are $85 \%$ water sample in hotel low in chlorine and $15 \%$ water sample in a hotel high in chlorine. Moreover, the standard plate count for hotel shows, about $28 \%$ water sample high in bacteria count and $71 \%$ water sample, low in bacteria count. Conversely, difference result show in a municipal water sample. Were there about $57 \%$ of water sample in municipal show low in chlorine level and $43 \%$ of the water sample is high in chlorine level. The standard plate count for municipal shows that $85 \%$ of the water sample is low in bacteria and about $15 \%$ water sample shows a high count in bacteria.

Table below show the result for the comparison of mean of physicochemical quality and microbiological quality. 


\begin{tabular}{|llll|}
\hline \multicolumn{2}{|l|}{ Adult swimming pool } & & \\
\hline Type & Apartment & Hotel & Municipal \\
\hline Chlorine (ppm) & $0.56 \pm 1.01$ & $0.77 \pm 0.95$ & $1.19 \pm 0.91$ \\
\hline
\end{tabular}

Table 3.1.1: Comparison of mean of physicochemical quality.

\begin{tabular}{|llll|}
\hline Adult swimming pool & & & \\
\hline Type & Apartment & Hotel & Municipal \\
\hline Standard plate count $(\mathrm{Cfu} / \mathrm{ml})$ & $28407.14 \pm 28469.05$ & $8192.86 \pm 10556.36$ & $3257.14 \pm 6250.17$ \\
\hline
\end{tabular}

Table 3.1.2: Comparison of mean of microbiological quality.

Frequency standard of the physicochemical parameters of swimming pools in Klang Valley, Malaysia presented in Table 3.1 while Table 3.2 shows the value of the standard plate count. The finding indicates that the chlorine and standard plate count of the apartment, hotel, and municipal water swimming pool.

3.2 Compere the mean of chlorine level quality in three difference group of apartment, hotel and municipal swimming pool in Klang Valley, Selangor.

Graph 3.2.1, shows the mean value of the chlorine for three types of swimming pool water sample the municipal show the higher value at $1.19 \pm 0.91$, followed by the hotel at $0.77 \pm 0.95$ and apartment at $0.56 \pm 1.01$ respectively. The $P$ value for Municipal is $0.018(<0.05)$ significantly higher than apartment and hotel.

\subsection{Compere the mean of standard plate count quality in three difference group of apartment, hotel and municipal swimming pool in Klang} Valley, Selangor.

And Graph 3.3.1 shows the mean value of the standard plate count for three types of the swimming pool water sample. The apartment shows the highest value of standard plate count at 28407.14 \pm 28469.05 , followed by Hotel at $8192.86 \pm 10556.36$ and the Municipal at $3257.14 \pm 6250.17$ respectively. The significant value of the apartment is $0.050(<0.05)$ highly significant compared to the hotel and municipal.

3.4 Correlation between standard plate count and chlorine level quality in three difference group of apartment, hotel and municipal swimming pool in Klang Valley, Selangor

\begin{tabular}{|llll|}
\hline Correlations & & & \\
\hline \multirow{2}{*}{ Chlorine Apartment } & & Chlorine Apartment & Bacteria Apartment \\
\cline { 2 - 4 } & Pearson Correlation & 1 & -0.124 \\
\cline { 2 - 4 } & Sig. (2-tailed) & 0.792 \\
\hline Bacteria Apartment & Pearson Correlation & -0.124 & 7 \\
\cline { 2 - 4 } & Sig. (2-tailed) & 0.792 & 1 \\
\cline { 2 - 4 } & $\mathrm{N}$ & 7 & 7 \\
\hline
\end{tabular}

Table 3.4.1: Correlation between Chlorine Apartment and Bacteria Apartment

A Pearson's correlation run to determine the relationship between Chlorine Apartment and Bacteria Apartment. There were a very weak, negative correlations between Chlorine Apartment and Bacteria Apartment $(r=-0.124, N=7, p=0.792(P>0.05)$. 


\begin{tabular}{|llll|}
\hline Correlations & & & \\
\hline \multirow{2}{*}{ Chlorine Hotel } & & Chlorine Hotel & Bacteria Hotel \\
\cline { 2 - 4 } & Sig. (2-tailed) & & -0.439 \\
\cline { 2 - 4 } & $\mathrm{N}$ & 7 & 0.325 \\
\hline Bacteria Hotel & Pearson Correlation & -0.439 & 7 \\
\cline { 2 - 4 } & Sig. (2-tailed) & 0.325 & 1 \\
\cline { 2 - 4 } & $\mathrm{N}$ & 7 & 7 \\
\cline { 2 - 4 } & & & 7 \\
\hline
\end{tabular}

Table 3.4.3: Correlation between Chlorine Hotel and Bacteria Hotel

A Pearson's correlation was run to determine the relationship between Chlorine Hotel and Bacteria Hotel. There was a moderate, negative correlation between Chlorine Hotel and Bacteria Hotel $(r=-0.439, N=7, p=0.325(P>0.05))$

Correlation value $r=-0.439$ of would be a "moderate negative correlation"

\begin{tabular}{|llll|}
\hline Correlations & & & \\
\hline \multirow{2}{*}{ Chlorine municipal } & & Chlorine municipal & Bacteria Municipal \\
& Pearson Correlation & 1 & -0.625 \\
\cline { 2 - 4 } & Sig. (2-tailed) & & 0.134 \\
\cline { 2 - 4 } & $\mathrm{N}$ & 7 & 7 \\
\hline Bacteria Municipal & Pearson Correlation & -0.625 & 1 \\
\cline { 2 - 4 } & Sig. (2-tailed) & 0.134 & 7 \\
\cline { 2 - 4 } & $\mathrm{N}$ & 7 & 7 \\
\cline { 2 - 3 } & & &
\end{tabular}

Table 3.4.5: Correlation between Chlorine Municipal and Bacteria Municipal

A Pearson's correlation run to determine the relationship between Chlorine Municipal and Bacteria Municipal. There was a strong, negative correlation between Chlorine Municipal and Bacteria Municipal $(r=-0.625, N=7, p=0.134(>0.05))$

Correlation value $r=-0.625$ of would be a "Strong negative correlation"

\section{Discussion}

In accordance with the WHO and ANSI/ APSP guidelines provided, swimming facilities must display regulations to identifying the correct activities to implement in the pool environment.

Seven samples random taken from apartment, hotels, and municipals swimming pool in Klang Valley, Selangor. The table and graft are the result occurrence of chlorine level and bacteriological status, analyzed. The chlorine level from the apartment's swimming pool shown about 
$85 \%$ water samples had low in chlorine level and other high in chlorine level. The standard plate count for seven apartment's swimming pool provide a result, high in bacteria with a result of $100 \%$.

Seven random swimming pool water sample had taken form hotels, the chlorine level is much similar with the apartment. Which there were $85 \%$ water samples show, low in chlorine and another $15 \%$ high in chlorine. The standard plate count for hotel swimming pool water shows about 28 $\%$ sample in the hotel have high bacteria count and $71 \%$ low in bacteria count.

There is a different result shown for the municipal's swimming pool water sample. Were there about $57 \%$ of water sample in municipal show low in chlorine level and other $43 \%$ have high in chlorine level. The standard plate count for municipal's swimming pool shows about $85 \%$ of the water sample are low in bacteria and others $15 \%$ having a high bacteria counts.

Notwithstanding, the standard level of chlorine in the swimming pool that had been standardized by WHO and ANSI/ APSP at 1.5 up to 4 PPU and the standard plate count should below $200 \mathrm{CFU} / \mathrm{ml}$. The result indicates that the municipal have good management of the swimming pool compared to hotel and apartment, this shows that the management of the apartment and hotel did not follow the recommended and guideline that had provided accordingly.

Moreover, as per investigation and observation, the growth of bacteria are due to a few factors where some of the swimming pool are the open swimming pool. The open swimming pool has access to an outbreak sources example birds, cats, dogs, frogs, rats, and insects. Some of the apartment and hotel contain feces of the birds and cats at the swimming pool area. The maintenance or the management of the swimming pool did not take upright maintenance to clean the swimming pool area from the feces. In addition, as per observation in the open swimming pool, there are a lot of birds and frogs take a shower at the bend of the swimming pool which increases the source of the bacteria.

The comparison, means of chlorine level quality in three different groups of the apartment, hotel and municipal swimming pool show, the apartment are the lower at $22 \%$ than the hotel and municipal by $34 \%$ and $44 \%$ respectively. This is due to some improper maintenance by apartment and hotel management. The level of chlorine should be monitoring every day to keep the swimming pool water low in photogenic bacteria and fungi. Using a low concentration of chlorine will affect the reading of the chlorine level and will increase the bacteria growth. This study support by Yoder et al., (2005) [16], said that improper maintenance of public and semi-public facilities frequently fails to protect the public against chlorine-sensitive pathogens, in addition, this statement supported by Al Khatib et al., (2003) [17], said that Analysis of the presence of free chlorine level for disinfection revealed that all samples contained free chlorine which is much less than the required level. Chorine used as disinfectant in all of the swimming pools and must be present continually and in sufficient concentrations in order to protect against survival of newly introduced pathogens, but the reasons might be using less amount and concentration of chlorine which may be incomparable to the volume of water, presence of high level of organic matter, microbial load, higher temperature (chlorine easily evaporate) and remains unavailable. By the latest article written by Kokebe Yedeme et al, (2017) [11], mention the physicochemical factors such as chlorine are very important key and controlled to ensure effective decontamination, to avoid damage to the pooled material and ensure user ease. If the water $\mathrm{pH}$ is alkaline, chlorine antiseptic enactment decrease, it will provide the growth of fungal. Generally, physicochemical parameters of the water have a strong influence on the efficiency of the disinfection process. Factors like $\mathrm{pH}$, the turbidity of the water, the concentration of chlorine and contact time, influence the efficiency of disinfection with chlorine.

Compare the mean of standard plate count in three different groups of the apartment, hotel, and municipal swimming pool show, the Standard plate count of the apartment is the highest at $71 \%$ compared with Hotel and municipal by $23 \%$ and $8 \%$ respectively. The bacteria in apartment is high due to contagion from the animal and bather and also low chlorine residual sanitization this supported study by Indabawa I.I, et al (2015) [14], said that the high bacterial count at the other sites prior to use by bathers and animal could probably come from contaminated water source or ineffective treatment of the swimming pools. All the pools had increment in bacterial load after use by bathers and animal, This is in conformity with the work of the workers who reported that bathers tend to shed bacteria from fecal and non-fecal sources, that increases the organic matter in the pool water, there will also be a lot of bacteria present working to decompose this matter. It also supported by Prescott et al, (2002) [15] said that it also isolated these species of fungi from public swimming pools in Egypt and Iran. Fusarium knew for ocular infections in humans and animal.

The result from the correlation analysis between standard plate count and chlorine level in three difference group of apartment, hotel and municipal swimming pool show, that there is week negative correlation between chlorine level in apartment and standard plate count in apartment with the correlation value of $r=-0.124$ with a significant value of $p=0.792$ which there is not significant. Moreover, the correlation test also thru between chlorine level hotel and standard plate count hotel which show a moderate negative correlation with a value of $r=-0.439$, with significant value $p=0.325$ result as no significant value. The test also completed to chlorine level municipal and standard plate count municipal; show the correlation value $r=-0.625$ which is a strong correlation but not significant with a value of $p=0.134$. Similar conclusions made by Rasti et al., (2012) [18] also reported no significant difference between the enduring chloride in contaminated and non-contaminated swimming pools. Moreover, Rabi et al. (2008) [19] also had the same support, that there is a correlation association between swimming pools adulteration and the 
time of water sample collection. In this result, Maida et al (2008) [20], claimed that the quality of water depends on chloride concentration and the number of swimmers appearing the pool.

\section{Conclusion}

In conclusion, bathers due to high bacteriological counts, resistant of those isolated microorganisms to chlorine commonly used for the treatment of the swimming pools and also to commonly available antibiotics. Swimming pool water recycled over more or less specified periods and various chemicals used to conserve water quality. Whilst there are numerous publications describing microbiological hazards in swimming pools. The results obtained in this study showed that swimming pools can constitute serious problems for society. Therefore, there is a need for the management of swimming pools to take proper care of their pools. This study is limited to a few samples because many of the municipal hotel and apartment managers refused to give us permission to collect samples from their swimming pools. However, the study manages to reveal the ineffectiveness of pool water disinfection in Klang Valley due to the fact that pathogenic bacteria isolated from the three categories of swimming pools. It concluded that the sanitary status of the selected pools was below international standards. Lastly, the study recommends improvement in personal hygiene of the swimmers, adequate disinfection of the pools and enforcement of national/international guidelines by the government.

\section{References}

[1] Brad Kelechava, (2015) Water Quality in Public Pools and Spas, American Public Health Association (APHA). 13 July 2015

[2] Osei-Adjei, G., Sarpong, S. K., Laryea, E., \& Tagoe, E. (2014). Bacteriological Quality Assessment of swimming pools in the Osu-Labadi Area, Accra. Journal of Natural Sciences Research, 4(19), 126-129. Retrieved from http://iiste.org/Journals/index.php/JNSR/article/view/15879

[3] Hoseinzadeh E, Mohammady F, Shokouhi R, et al. (2013), Evaluation of biological and physico-chemical quality of public swimming pools, Hamadan (Iran). Int J Env Health Eng 2013; 2(1): 21.

[4] Yoder, J.S., Gargano, J.W., Wallace, R.M., Beach, M.J., 2012a. Giardiasis surveillance United States, 2009e2010. MMWR Surveill. Summ. 61 (5), $13 e 23$

[5] Yoder, J.S., Wallace, R.M., Collier, S.A., Beach, M.J., Hlavsa, M.C., Centers for Disease Control and Prevention (CDC), 2012b. Cryptosporidiosis surveillance United States, 2009e2010. MMWR Surveill. Summ. 61 (5), 1 e12.

[6] Brewster DH, Brown MI, Robertson D, Houghton GL, Bimson J, Sharp JC.( 1994). An outbreak of Escherichia coli 0157 associated with childrens paddling pool. Epidemiol Infect.; 112(3):441-7.

[7] Kiyohara N, Kobayakawa Y, Lyman H, Osafune T. (2006). Identification of bacterial flora in the water of swimming pools throughout the year. Japan J PhysEduc HIth Sport Sci. 51(1):1-9

[8] WHO, (2006). Microbial hazards. In: Guidelines for Safe Recreational Water Environments. Swimming Pools and similar Environments, vol. 2. WHO Press, Geneva, Switzerland, pp. 26-59 (Chapter 3).

[9] WHO, (2006). Managing water and air quality. In: Guidelines for Safe Recreational Water Environments. Swimming Pools and similar Environments, vol. 2. WHO Press, Geneva, Switzerland, pp. 80-99 (Chapter 5).

[10] CDC (2001a) Prevalence of parasites in fecal material from chlorinated swimming pools - United States, 1999. Morbidity and Mortality Weekly Report, 50: 410-412

[11] Kokebe Yedeme, Melese Hailu Legese, Almaz Gonfa and Somson Girma. (2017). Assessment of Physicochemical and Microbiological Quality of Public. The Open Microbiology Journal, 2017, 11, 98-104

[12] JPM. (2015). Laporan tahunan 2015 Jabatan Perangkaan Malaysia.

https://www.dosm.gov.my/v1/uploads/files/4_Portal\%20Content/1_About\%20us/7_AnnualReport/Laporan_Tahunan_2015_D0SM.pdf

[13] American Public Health Association (APHA). (1985) Standard Methods for the Examination of water and waste water. 16th edition, Washington, D.C.

[14] Indabawa, I. I., Ali, S., \& Mukhtar, M. D. (2015). Assessment of Microbiological and Physico- Chemical Quality of Some Swimming Pools within Kano Metropolis , Kano Nigeria.

[15] Harley, J.P. and Prescott, L.M. (2002) Laboratory Exercises in Microbiology. 5th Edition, The McGraw-Hill Companies. 
[16] Yoder, J.S., Hlavsa, M.C., Craun, G.F., Hill, V., Roberts, V., Yu, P.A., Hicks, L.A., Alexander, N.T., Calderon, R.L., Roy, S.L., Beach, M.J., 2008. Surveillance for waterborne disease and outbreaks associated with recreational water use and other aquatic facility-associated health eventsdUnited States, 2005e2006. MMWR Surveill. Summ. 57

[17] Al-Khatib, I. and Salah, S. (2003). Bacteriological and chemical quality of swimming pools water in developing countries: A case study in the West Bank of Palestine. International Journal of Environmental Health Research, 13(1): 17-22. (PDF) Quality Assessment of Selected Public Swimming Pools in Owerri Metropolis, Nigeria. Available from:

https://www.researchgate.net/publication/299411514_Quality_Assessment_of_Selected_Public_Swimming_Pools_in_Owerri_Metropolis_Nigeria [accessed Dec 27 2018].

[18] Rasti, S., Assadi, M. A., Iranshahi, L., Saffari, M., Gilasi, H. R., \& Pourbabaee, M. (2012). Assessment of microbial contamination and physicochemical condition of public swimming pools in Kashan, Iran. Jundishapur Journal of Microbiology, 5(3), $450-455$.

https://doi.org/10.5812/jjm.2478

[19] Rabi, A., Khader, Y., Alkafajei, A., \& Aqoulah, A. A. (2008). Sanitary Conditions of Public Swimming Pools in Amman , Jordan Sanitary Conditions of Public Swimming Pools in Amman , Jordan, (October). https://doi.org/10.3390/ijerph5030152

[20] Maida, C. M.; Di Benedetto, M. A.; Firenze, A.; Calamusa, G.; Di Pazza, F. and Milici, M. E. (2008). Surveillance of the Sanitary Conditions of a Public Swimming Pools in the City of Palermo (Italy).1g.sanita pubbl .649(5): 281-293.

[21] Dr Milton Lum,(2015) The Star online, Infections and water https://www.thestar.com.my/lifestyle/health/2015/01/18/infections-andwater/\#1WbibP1 wi0yvgKdA.99

\section{Graphs}

The graphs are available in the Supplementary Files.

\section{Supplementary Files}

This is a list of supplementary files associated with this preprint. Click to download.

- Graph3.2.1.png

- Graph3.3.1.png

- Graph3.4.2.png

- Graph3.4.4.png

- Graph3.4.6.png 